\title{
Ocal siebie, aby ocalić świat - filozofia Małego Księcia
}

\begin{abstract}
The main research task of the paper is to reconstruct The Little Prince's philosophy. It is a philosophy of humanism created as a response to the spiritual crisis of Western culture. The mission of this philosophy is to save humans to save the world of fundamental values such as love, friendship, and responsibility. It is also the philosophy of the meeting, which enters into a dialogue with representatives of the philosophical tradition (Schopenhauer, Nietzsche, Žižek) and popular culture artists.
\end{abstract}

Keywords: The Little Prince, Antoine de Saint-Exupéry, humanism, philosophy in literature, philosophy and popular culture

\section{Wstęp}

$\mathrm{M}$ ały Książę był i jest obiektem badań naukowych wykraczających często poza analizy stricte literaturoznawcze. Dzieło Antoine’a de Saint-Exupéry’ego można badać w kontekście pedagogicznym, analizując je jako narzędzie pomocne w przeprowadzeniu procesu socjalizacji i wdrażania dzieci w kulturę ${ }^{2}$. W badaniach religioznawczych wskazuje się na duchowy wymiar przesłania książki, a także na obecność symboliki, którą można interpretować religijnie. Podejmowane są także

${ }^{1}$ A. de Saint-Exupéry, Mały Ksiq̨żę, tłum. E. Łozińska-Małkiewicz, ALGO, Toruń 1998.

2 M. Potočárová, The educational and moral message in Antoine de Saint Exupéry's The Littel Prince, „Studia Paedagogica Ignatiana” 4(20)/2017, s. 69. 
próby chrystianizacji historii Małego Księcia i opisania jej w języku przypowieści ewangelicznych ${ }^{3}$, co wymaga jednak przeprowadzenia Gadamerowskiej „fuzji horyzontów”, w ramach której spotkają się idee chrześcijaństwa i filozoficznego humanizmu, z perspektywy którego napisana jest książka. I choć w Małym Księciu bezpośrednio nie pojawiają się odniesienia do Boga (który jest największym nieobecnym książki) lub religii, to wspomniany dialog może wydarzyć się na poziomie etycznych ideałów, które humanizm Saint-Exupéry’ego i wiara chrześcijańska współdzielą. Przygody Małego Księcia są także wyzwaniem dla badań psychologicznych lub psychoanalitycznych ${ }^{4}$. W takim przypadku kluczem do ich zrozumienia są wątki biograficzne z życia Saint-Exupéry’ego, a sama książka okazuje się oknem umożliwiającym wniknięcie w skomplikowaną psychikę jej autora. W ten sposób historia Róży staje się historią kobiet, z którymi autor Małego Księcia był związany (przede wszystkim żony Consuelo de Saint-Exupéry i matki Marie de Fonscolombe), a spotkanie Pilota rozbitka z tajemniczym chłopcem staje się powrotem autora do własnego dzieciństwa, natomiast samo napisanie książki może być postrzegane jako próba terapeutycznego działania mającego na celu przezwyciężenie egzystencjalnego kryzysu związanego z licznymi depresjami.

Na najbardziej podstawowym poziomie Mały Ksiq̨żę nie jest jednak literackim traktatem pedagogicznym, religijnym lub psychologicznym. Nie odrzucając tych wszystkich hermeneutyk interpretacji dzieła Saint-Exupéry’ego, trzeba podkreślić, że stworzył on przede wszystkim uniwersalną powiastkę filozoficzną. Za uznaniem

3 Taką chrześcijańską interpretację zaproponował ks. Adam Świeżyński, który książkę Saint-Exupéry’ego odczytuje jako zaproszenie do Ewangelii skierowane do tych osób, które poszukują spotkania z Absolutem będącym transcendentnym punktem odniesienia dla naszej egzystencji. Ewangeliczny wymiar mają zwłaszcza ostatnie chwile życia Małego Księcia, które wykazują pewne podobieństwo do ostatnich dni Jezusa. Mały Książę, tak jak Jezus, zapowiada swoje odejście. Gdy żegna się z Pilotem, ten trzykrotnie zapewnia, że go nie opuści, w czym staje się podobny do św. Piotra, który też zapewniał swego Mistrza o swej niezłomnej wierności. Pilotowi nie obce jest także doświadczenie „pustego grobu”, gdyż o świcie nie znajduje ciała Małego Księcia. Szerzej zob. A. Świeżyński, „Czy baranek zjadł różę?”. Próba symbolicznobiblijnej interpretacji Małego Księcia Antoine’a de Saint-Exupéry’ego, „Studia Gdańskie” XXI, 2007, ss. 94-95, 98. Natomiast w ostatnich słowach Pilota, w których prosi on o informacje o ponownym pojawieniu się jego przyjaciela, wybrzmiewa mesjańskie wyczekiwanie na ponowne przyjście wybawiciela, który posiada moc przemieniania serc. Wyrazem zrealizowania mesjańskiej misji mogą być też, wypowiedziane przed śmiercią, słowa Małego Księcia: „Otóż to. To wszystko”. W tych słowach wybrzmiewa echo słów umierającego Jezusa: „Wykonało się!” (J 19,30). Mały Ksiq̨żę odczytywany literalnie nie jest religijną przypowieścią, ale jego duchowe przesłanie można uznać za zgodne z chrześcijańskim przykazaniem miłości bliźniego. Szerzej zob. E. Drewermann, Istotnego nie widać: rzecz o Małym Księciu, tłum, J. Prokopiuk, W.A.B., Warszawa 1996, ss. 121-125, 162; A. Bukowska, Saint-Exupéry czyli paradoksy humanizmu, PIW, Warszawa 1970, ss. 36, 125-126, 164; W. Kwiatkowski, Saint-Exupéry w świetle krytyki, w: idem (red.), Humanizm Saint-Exupéry’ego, Pax, Warszawa 1969, s. 126; B.C. Meyer, The Little Prince: speculations on the disappearance of Antoine De Saint-Exupéry, „Journal of American Psychoanalytic Association” 1(22)/1974, ss. 150, 155-156.

${ }^{4}$ E. Drewermann, Istotnego nie widać..., s. 11. 
książki za powiastkę filozoficzną przemawia jej luźna i przystępna forma fabularna, która jednak służy przedstawieniu poważnych idei i dylematów filozoficznych, gdyż Mały Ksiq̨żę jest głosem w obronie humanizmu ${ }^{5}$, analizą różnych typów miłości oraz opowieścią o tworzeniu lub odnajdywaniu samego siebie. Książka zawiera także wyraźne wątki dydaktyczne i jest wyrażoną nie wprost krytyką pogrążonych w kryzysie zachodnich społeczeństw XX wieku. Dzięki tym właściwościom dzieło francuskiego pisarza jest jednocześnie piękną baśnią dla dzieci i mądrościową księgą dla dorosłych, dziełem kultury popularnej i arcydziełem światowego kanonu literatury.

Zadaniem artykułu jest wydobycie na powierzchnię treści filozoficznych ukrytych w historii Małego Księcia, a także pokazanie, że zawartą w książce filozofię Saint-Exupéry’ego można znacznie pogłębić i rozbudować poprzez wykorzystanie do jej interpretacji idei czerpanych od takich myślicieli, jak Artur Schopenhauer, Fryderyk Nietzsche lub Slavoj Žižek. W punkcie wyjścia przyjmuję, że głównym zadaniem filozofii Małego Księcia jest zachęcenie do podjęcia trudu misji ratowania nas samych przed zagrożeniem dehumanizacji. Misja ta może zakończyć się sukcesem tylko wtedy, gdy źródła ocalenia poszukamy na drodze wspólnego porozumienia będącego podstawą zawiązania się wspólnoty. Tylko w ten sposób ocalimy siebie, innych i nasz wspólny świat.

\section{Filozofia Małego Księcia jako droga do ocalenia samego siebie}

\subsection{Ambiwalencja pustyni}

Już pierwsze sceny przedstawiające spotkanie Pilota z tajemniczym chłopcem prowokują do nadania im filozoficznej interpretacji. Spotkanie bohaterów, dla którego sceną jest pustynia, staje się początkiem ich wspólnej przygody, z której zrodzi się doświadczenie przyjaźni, dzięki której otwiera się droga do głębokiej duchowej przemiany. W tym zaskakującym zejściu się dwóch bardzo odmiennych osób, kwestią sporną jest pytanie: kto spotyka kogo? Kim tak naprawdę są Pilot i Mały Książę? Obaj bohaterowie nie przemawiają jedynie we własnym imieniu, ale są przede wszystkim reprezentantami dwóch różnych światów - dorosłych i dzieci. Dorosły Pilot spotyka dziecko, czyli swojego Innego. Każdy dorosły był jednak kiedyś dzieckiem, dlatego to spotkanie z dzieckiem-Innym można odczytywać jako

\footnotetext{
${ }^{5}$ Władysław Kwiatkowski wyróżnia dwa typy humanizmu obecne w twórczości francuskiego pisarza. Pierwszy z nich to humanizm bohaterski, w którym odnajdujemy ideały nietzscheanizmu, takie jak: przezwyciężanie samego siebie poprzez wznoszenie się ponad własne ograniczenia i zmagania ze stawiającą opór naturą. W Małym Księciu dominuje drugi typ, który jest humanizmem międzyludzkich więzi, powiązanym z wpływem idei chrześcijańskich. Zob. W. Kwiatkowski, Saint-Exupéry: samotność i więź, Wydawnictwo Uniwersytetu Marii CurieSkłodowskiej, Lublin 2003, ss. 14-15.
} 
ponowne odkrycie tego, co było kiedyś swojskie, ale w świecie dorosłych zostało zapomniane lub wyparte. Inny nie jest więc całkiem obcy, a to otwiera drogę do stwierdzenia, że w tym pustynnym spotkaniu tak naprawdę Pilot spotyka samego siebie skrywającego się pod postacią dziecka.

Drugim ważnym elementem tego spotkania jest samo miejsce jego zajścia, czyli pustynia. Z jednej strony pustynię można postrzegać jako miejsce odosobnienia lub azylu dla uciekających od duchowej pustki nowoczesnych miast molochów. Bycie na pustyni pozwala doświadczyć samotności, jednakże jest to samotność innego typu niż ta, której doświadczają zatomizowane jednostki z nowoczesnych miast, a którą często określa się mianem samotności w tłumie. W samotności przebywania na pustyni rodzi się możliwość odnalezienia samego siebie lub odzyskania tego, co zostało utracone. W takim przypadku pustynia nie jest miejscem samotnego umierania, a raczej przestrzenią, w której można narodzić się na nowo. Tam, gdzie rozpada się zaawansowana cywilizacja (symbolizowana przez rozbity samolot Pilota), rodzi się nowa duchowość. To duchowe odrodzenie potrzebne jest Pilotowi, który trafia na pustynię w stanie wewnętrznego spustoszenia. W tym przypadku pustynia nie odnosi się już do pustynnego miejsca, lecz do wewnętrznej pustyni ducha. To właśnie pustynia jako realne miejsce bywała jednak nierzadko miejscem duchowych starć. Jednym z najbardziej znanych przykładów takiego starcia było kuszenie Jezusa, który czterdzieści dni pościł na pustyni. W książce Exupéry’ego takim starciem jest zderzenie się dziecięcego i dorosłego sposobu postrzegania świata, które pierwszy raz zamanifestowały się w słynnej scenie interpretacyjnego sporu o kapelusz, który tak naprawdę miał być wężem boa pożerającym słonia. Spojrzenie dorosłych charakteryzuje płytki materializm i minimalistyczny redukcjonizm charakterystyczny dla nowoczesności zdominowanej przez racjonalność instrumentalną, natomiast spojrzenie dziecka związane jest z czułością „postrzegania sercem”. Idea „postrzegania sercem” jest bardzo poetycka, a przez to niejednoznaczna i podatna na różnorodne interpretacje. Próbując jednak ukonkretnić sposób jej rozumienia, można wskazać przynajmniej na trzy ważne elementy ją konstytuujące. Po pierwsze, „postrzeganie sercem” wiąże się z dowartościowaniem wyobraźni, dzięki której można uzyskać lepszy wgląd w istotę rzeczy i zobaczyć coś więcej niż tylko zwykły kapelusz. Po drugie, „postrzeganie sercem” związane jest także z odrzuceniem wspomnianego już wcześniej prymatu rozumu (skupionego na racjonalizacji wszelkich aspektów życia i podporządkowaniu działania wymogowi ekonomicznej opłacalności), którego przejawami są postawy reprezentowane przez niektórych dorosłych spotykanych przez Małego Księcia. Byłaby to na przykład potrzeba absolutnego panowania reprezentowana przez Króla, którego można potraktować jako ucieleśnienie rozumu, gdyż wydaje jedynie racjonalne, zgodne z naturą rozkazy (np. nie wyda polecenia, aby generał przemienił się w ptaka). Owo panowanie Króla/rozumu jest tylko pozorne, gdyż zachód słońca nie następuje na jego rozkaz, a jest jedynie następstwem naturalnych procesów. To pokazuje, że 
pretendowanie do panowania rozumu nad naturą jest jedynie próbą uzurpowania władzy, która do niego nie należy. Rozum nie włada naturą, nie konstruuje jej praw, a jedynie je odkrywa i opisuje. Wypaczone oblicze rozumu ukazuje także postawa Biznesmena, który swoje działanie zawęża do nieustannego kalkulowania, przedstawiania wszystkiego poprzez ciągi liczb i redukowania tego, co duchowe do poziomu środka pozyskiwania ekonomicznych korzyści. W ten sposób gwiazdy przestają być inspiracją dla „leniwych marzycieli”, a stają się jedynie środkiem do pozyskiwania kolejnych środków służących do nieustannego powiększania bogactwa. Minusem rozumu jest także skłonność do schematyzowania i upraszczania rzeczywistości, czego przejawem jest zachowanie Geografa, czystego teoretyka będącego „gabinetowym uczonym”6. Tworzy on mapy świata, które są jednak bardzo niedokładne, gdyż nie ewidencjonują jednej małej róży. Przedstawiony na nich świat jest więc bardzo uproszczony i nie oddaje wielości i różnorodności otaczających nas bytów. Geograf niczym platonik skupia się tylko na bytach odwiecznych, tylko one są na tyle doniosłe i spektakularne, aby przykuć uwagę rozumu, dla którego przemijająca róża nie jest godnym obiektem refleksji. Wreszcie po trzecie, „widzenie sercem” pozwala dostrzec prawdziwą istotę więzi, o których wspomina Lis. O tym, czy więź pomiędzy osobami jest prawdziwie autentyczna i szczera, nie przesądzają takie jej materialne przejawy, jak drogi pierścionek lub inne prezenty. Czasu poświęconego na pielęgnowanie miłości nie można zobaczyć, ale można go doświadczyć sercem. W pewnym uproszczeniu można przyjąć, że spojrzenie dziecka jest bardziej romantyczne, a spojrzenie dorosłych zdecydowanie bardziej oświeceniowo-scjentystyczne. Taki podział bardzo mocno jest obecny także w poetyckiej balladzie Adama Mickiewicza Romantycznośćn ${ }^{7}$ w której to poeta mądrość „szkiełka i oka” przeciwstawia duchowemu czuciu wiary. Apel: „miej serce i patrzaj w serce” idealnie współgra z przeświadczeniem, że serce dostrzega wszystko to, czego oko nie może spostrzec, a to wskazuje na duchowe powinowactwo obu utworów.

\subsection{Asteroida jako „mały świat”}

Tym, co wywołuje w nas stan duchowego spustoszenia, jest rozpad naszego prywatnego, intymnego „małego świata”. Świat jako taki może sprawnie funkcjonować, a mimo tego gdzieś w głębokim wnętrzu człowieka może dochodzić do gwałtownego procesu rozpadu tego, co można nazwać naszą indywidualną relacją lub nastawieniem do rzeczywistości, w której żyjemy. Tworząc indywidualne relacje

${ }^{6}$ D. Borowski, Literackie nawiqzzania do Małego Księcia Antoine’a de Saint- Exupéry’ego spojrzenie intertekstualne, w: Z. Ożóg-Winiarska (red.), Teksty kultury w edukacji polonistycznej i refleksji badawczej, Wydawnictwo Uniwersytetu Jana Kochanowskiego, Kielce 2014, s. 42.

${ }^{7}$ A. Mickiewicz, Romantyczność, https://wolnelektury.pl/katalog/lektura/ballady-i-romanseromantycznosc.html [27.11.2019]. 
z różnorodnymi elementami składającymi się na otaczający nas świat, tworzymy „mały świat” naszego osobistego życia. Jest to więc świat zabarwiony naszym subiektywizmem oraz nadawanymi przez nas sensami i wartościami. Jest to świat, w którym wszystko nabiera wyjątkowego znaczenia dzięki temu, że wytwarzamy indywidualne relacje do tego, co w życiu napotykamy. Sala wykładowa, w której cotygodniowo wydarza się intelektualna przygoda, nie jest jedną z wielu takich samych sal, jakich pełno na całym świecie. Jest tą jedną jedyną salą, w której jakiś moment naszego życia się wydarza, a my nadajemy mu sens, integrując w strukturę naszego „małego świata”. Więzi wytworzone z tym miejscem oraz z napotkanymi tam osobami sprawiają, że to miejsce staje się czymś wyjątkowym. Dokładnie zrozumiał to także Mały Książę, gdy uświadomił sobie, że jego Róża nie jest jedną z tysiąca róż, ale jest tą jedyną, gdyż tylko z nią nawiązał on wyjątkową więź i tylko ona była częścią jego „małego świata”.

W twórczości Exupéry’ego pojawia się ważne odróżnienie obszaru od przestrzeni, które Władysław Kwiatkowski opisuje w następujący sposób:

Aby dokładniej zrozumieć jeden z głównych aspektów Małego Księcia, należy wyjaśnić sens terminów, które ze szczególną intensywnością pojawiają się w książkach Saint-Exupéry'ego pisanych podczas wojny i pełnią w nich istotną funkcję: obecność (présence) i ściśle z nią związany obszar (étendue), przeciwstawiony przestrzeni (espace). [...] Saint-Exupéry mówi o étendue, gdy istnieje więź między nią a świadomością człowieka, gdy zahacza ona o ludzką psychikę i przyciąga jak magnes. Nie jest już wówczas obcą, abstrakcyjną, nic nie znaczącą przestrzenią. Étendue staje się tym bogatsza i godna miłości, im więcej utkanych jest psychicznych powiązań między nią a świadomością. Człowiek buduje ją w sobie i staje się ona drogocennym składnikiem jego wewnętrznego świata9 .

W świecie Małego Księcia takim bezpośrednim otoczeniem/obszarem, bańką „małego świata” jest jego asteroida. W takim przypadku baranek, wulkany, Róża, to napotykane wewnątrzświatowe byty, z którymi Mały Książę tworzy więzi nadające im wyjątkowe znaczenie dla jego życia. Owo bycie-ku, zwrócenie się ku innym bytom i wytwarzanie więzi jest procesem upadania w świat, jest uczeniem się zamieszkiwania świata, czyli tym, co Saint-Exupéry określa mianem oswajania świata lub zakorzeniania się w nim ${ }^{10}$. Upadanie i oswajanie świata wytwarza ten wyjątkowy obszar najbliższego otoczenia naszego „małego świata”.

Nie jest to jednak świat odporny na różnego rodzaju dezintegrujące go zagrożenia. Tak jak symbolicznym przedstawieniem „małego świata” jest asteroida

${ }^{8}$ Inspirację dla koncepcji „małego świata” czerpię z idei bezpośredniego otoczenia/ środowiska naszego życia (Umwelt), która pojawia się we wczesnych pismach Martina Heideggera. Zob. M. Heidegger, Bycie i czas, tłum. B. Baran, Wydawnictwo Naukowe PWN, Warszawa 2005, s. 83.

${ }^{9}$ W. Kwiatkowski, Saint-Exupéry: samotność..., s. 78.

${ }^{10}$ Ibidem, s. 82. 
Małego Księcia, tak baobaby są ucieleśnieniem wszelkich zagrożeń mogących zakłócić jego funkcjonowanie. Tym zagrożeniem mogą być wszelkiego rodzaju traumatyczne wydarzenia, takie jak rozstania, śmierci bliskich osób lub wojna. W takich przypadkach wytworzona więź zostaje przerwana, a bańka „małego świata” pęka. Używając jeszcze innej metafory, zaczerpniętej od Kuby Mikurdy i Slavoja Žižka, można stwierdzić, że następuje wtedy wylogowanie się z naszego systemu operacyjnego, do którego można ponownie się zalogować dopiero, gdy nasz „mały świat” ulegnie rekonstytucji ${ }^{11}$.

Jak jednak odtworzyć bańkę „małego świata” zniszczoną w wyniku utraty bliskiej osoby? Tradycyjnym środkiem pomocy oferowanym od wieków przez kultury całego świata jest zalecenie odprawienia odpowiedniego rytuału, w przypadku śmierci bliskiej osoby będzie to rytuał żałobny (w przypadku rozstania będzie to wybaczenie prowadzące do pojednania). Odpowiednie przepracowanie okresu żałoby prowadzi do pogodzenia się z utratą kochanej osoby. Jeśli, za pomocą rytuałów, żałoba nie zostanie odpowiednio przepracowana, to pojawia się zagrożenie popadnięcia w zniewalającą nas melancholiczną nostalgię, czyli stan niepogodzenia się z utratą bliskiej osoby. W takim przypadku staramy się żyć tak, jakby ukochana osoba była nadal z nami, jednakże realny brak jej obecności sprawia, że nasze oczekiwania nijak mają się do rzeczywistości codziennego życia, a z tego rozczarowania rodzi się właśnie melancholijny nastrój²

Aby przezwyciężyć melancholię, Mały Książę musi wybaczyć Róży oraz samemu sobie. Dopiero wtedy otworzy się droga do odnowy przeciętej więzi i rekonstytucji ich „małych światów”, w tym przypadku częściowo nachodzących na siebie i tworzących zbiór wspólny. Podobne wyzwanie stoi także przed Pilotem, który by nie popaść w niszczącą melancholię, musi przepracować żałobę po śmierci Małego Księcia. Musi pozwolić mu odejść, co jednak nie oznacza wymazania go z pamięci, gdyż łącząca ich wieź nadal trwa, przyjmując jedynie inną formę.

${ }^{11}$ S. Žižek, Lacrimae rerum. Kieślowski, Hitchcock, Tarkowski, Lynch, tłum. G. Jankowicz, J. Kutyła, K. Mikurda, P. Mościcki, Wyd. Krytyki Politycznej, Warszawa 2007, ss. 20, 103-115.

${ }^{12}$ Zygmunt Freud utożsamiał melancholię ze stanem chorobowym, związanym raczej z miłosnym rozczarowaniem. W jego wyniku dotychczasowa miłość kierowana w stronę obiektu pragnienia zaczyna mieszać się z nienawiścią, a ta w stanie melancholii zostaje przeniesiona na własne Ja, któremu zaczynamy przypisywać negatywne cechy obiektu pragnienia. To prowadzi do gwałtownego samooskarżania, które w skrajnych przypadkach może przyjmować sadystyczną formę i prowadzić nawet do prób samobójczych. Zob. Z. Freud, Żałoba i melancholia, tłum. B. Kocowska, w: K. Pospieszył (red.), Zygmunt Freud: człowiek i dzieło, Zakład Narodowy im. Ossolińskich, Wrocław 1991, ss. 295-308. Zwróćmy uwagę na to, że także Mały Książę po rozstaniu z Różą w pewnym momencie zaczyna oskarżać sam siebie, przypisując sobie wady Róży, przede wszystkim brak chęci otwarcia się i zrozumienia potrzeb bliskiej osoby. A. de Saint-Exupéry, Mały Ksiq̨żę..., s. 28. 


\subsection{Więź z Różą jako kobietą fatalną}

W „małym świecie” Małego Księcia najważniejszą i zarazem najtrudniejszą więzią jest ta łącząca go z tajemniczą Różą, której zniewalające piękno zrodziło się wraz ze wschodem słońca. To właśnie z oswojenia Róży powstało niełatwe doświadczenie miłości jako erosa ${ }^{13}$, którego pragnieniem jest posiadanie kogoś wyjątkowego na wyłączność. Dlatego Małego Księcia tak bardzo zasmucił widok różanego ogrodu, który pozornie odbierał wyjątkowość jego Róży. To dlatego barankowi trzeba nałożyć kaganiec (ma to być ochrona przed zjedzeniem, czyli skonsumowaniem związku z Różą), gdyż zaborcza miłość erosa nie chce dzielić się obiektem swego pragnienia, nie chce, aby ktoś inny go posiadł. Eros jest także tym typem miłości, który należy do najbardziej burzliwych i wprowadzających zamęt w ludzkie życie. Strzała kupidyna przynosi też ból i cierpienie miłości. Tak jest również w przypadku Małego Księcia, tym bardziej że w postaci Róży można dostrzec cechy kobiety fatalnej. Róża jest kobietą niebezpieczną, gdyż ma aż cztery bardzo ostre kolce. Bliski kontakt z nią może ranić. Celem jej istnienia jest wzbudzać poczucie winy, potrafi więc dręczyć niczym nocna mara. Róża koloru czerwonego wpisuje się także w często spotykany wizerunek rudowłosej femme fatale, takiej jak choćby Dagny Juel-Przybyszewska. Najważniejszą cechą kobiety fatalnej jest jednak to, że miłość do niej ściśle związana jest ze śmiercią. Nie inaczej jest w przypadku Małego Księcia, który umiera, aby powrócić do swej Róży. To wszystko sprawia, że jego eros przepełniony jest melancholią wynikającą z rozejścia się idealistycznych fantazji o miłości snutych podczas spoglądania w gwiazdy i realiów szorstkiej rzeczywistości codziennego współbycia. To właśnie melancholijność erosa sprawia, że Mały Książę woli zachody, a nie wschody słońca.

Czy można jednak powiedzieć, że Róża jedynie wykorzystuje Małego Księcia i tak naprawdę go nie kocha? Odpowiedź twierdząca byłaby niesprawiedliwą

${ }^{13}$ Inną interpretację przedstawia Eugen Drewermann, który w wątku Róży i Małego Księcia doszukuje się autobiograficznych elementów z wczesnego dzieciństwa Saint-Exupéry’ego. Dlatego w relacji do Róży dopatruje się miłości do matki, a nie żony francuskiego pisarza. Przemawiać za tym mają cytowane przez niego listy autora Ziemi, planety ludzi wskazujące na jego bardzo mocne przywiązanie do matki, określanej wręcz mianem jego wielkiej miłości, którą pisarz bardzo chciał się opiekować. Zob. E. Drewermann, Istotnego nie widać..., ss. 78, 84, 98-102. Drewermann interpretuje Małego Księcia, wykorzystując przede wszystkim idee psychoanalityczne, a w takim przypadku może dojść do zlania się postaci matki i ukochanej partnerki, gdyż zgodnie z Freudowskim postulatem mężczyzna w przyszłej partnerce szuka jakiegoś podobieństwa do własnej matki. Niemiecki badacz przytacza znamienny fragment z listu Saint-Exupéry’ego, w którym stwierdza on, że jeśli tylko jego matka tego zechce, to ożeni się z nią. Zob. ibidem, ss. 100, 133. W dalszej części artykułu Różę traktuje jako sympatię Małego Księcia, a nie jego matkę, nie wnikając jednak, w jakim stopniu można ją utożsamiać z żoną Saint-Exupéry’ego (która pochodziła z Salwadoru, nazywanego czasem „ziemią wulkanów”, a jej autobiografia nosi tytuł Pamiętnik róży). 
oceną Róży, która kocha Małego Księcia, ale uświadamia to sobie dopiero wtedy, gdy on odchodzi. Tutaj objawia się złośliwa natura erosa, który przychodzi zbyt późno, dopiero w tym momencie, w którym kogoś tracimy. Róża jest też zazdrosna o wszystko, co przyciąga uwagę Małego Księcia i odciąga jego spojrzenie od niej, a wyruszając w podróż, może on spotkać setki innych róż, które go oswoją. Gwałtowny rozkwit uczuć Róży, która nagle uświadamia sobie, co utraciła wraz z odejściem Małego Księcia, dobrze opisuje także parafraza Mickiewiczowskich słów o miłości, którą docenia się dopiero w momencie jej utraty.

\subsection{Etyka troski o innych}

Tworząc nasz „mały świat”, troszczymy się o samych siebie, starając się zadomowić w strukturach otaczającej nas rzeczywistości. Wszystko co nas otacza, odnosimy do siebie, wszystkiemu nadajemy jakiś nasz sens, wszystko wartościujemy, decydując o formie wytwarzanej więzi. W świecie jako takim jesteśmy jedynie jednym z wielu jego licznych elementów, w naszym „małym świecie” jesteśmy ulokowani w jego samym centrum i wszystko kręci się dookoła nas. „Mały świat” jest konstruktem naszego Ja i nikt inny nie ma do niego takiego wglądu jak my sami. Z taką egocentrycznością wiążą się jednakże różnego rodzaju zagrożenia zmieniające „mały świat” w więzienie dla Ja, które zamyka się na innych.

Człowiek próżny, spotkany przez Małego Księcia na jednej z odwiedzanych planet, jest zapatrzony w siebie, innych potrzebuje tylko do tego, aby go wielbili. Popadając w próżność, otaczamy się wieloma przedmiotami i na zewnątrz nasza egzystencja wydaje się przez to bogata, jednak wnętrze takiego „małego świata” jest bardzo puste, gdyż więzi wytworzone z tymi przedmiotami są bardzo powierzchowne, są one cenne tylko jeśli przynoszą poklask. Tego, czego tu brakuje, to otwarcie się na więziotwórczą moc daru. Podzielenie się z innymi własnymi dobrami wytwarza więzi, które pozwalają wyjść z pułapki zafiksowania na własnym Ja. W świecie Małego Księcia takim cennym dobrem, które możemy ofiarować innym, jest czas spędzany z nimi. Jeszcze trudniejszym i przygnębiającym przypadkiem jest los Pijaka, który na swojej planecie pragnie zapomnieć o wszystkim, także o swoim własnym Ja. Człowiek, który utraci zdolność tworzenia jakichkolwiek więzi, odcina się od wszystkiego, co go otacza, i zapada się w pustkę swojego „małego świata”, w którym jest już miejsce jedynie na anestetyki znieczulające cierpienie ${ }^{14}$.

Filozofia Saint-Exupéry’ego próbuje wyjść poza takie niebezpieczne zawężenie własnej egzystencji do kultywowania własnego Ja i do postulatu troski o siebie dodaje troskę o innych. To przesłanie najmocniej wybrzmiewa w nauczaniu Lisa ${ }^{15}$,

${ }^{14}$ M. Jung, Mały Ksiq̨żę w nas: w podróży odkrywczej z Saint-Exupérym, Księgarnia Świętego Wojciecha, Poznań 2006, ss. 39-54.

${ }^{15}$ Do historii Lisa odwołuje się także japoński psychoanalityk Takeo Doi, który próbował przybliżyć zachodnim badaczom istotę jego koncepcji amae. Zob. T. Doi, On the concept of 
w którym wyróżnić można trzy ważne aspekty. Po pierwsze, gdy Lis opowiada Małemu Księciu o przyjaźni, do której dochodzi się poprzez oswajanie innych, czyli wytwarzanie więzi, podkreśla, że ten proces oswajania musi być stopniowy. Mały Książę nie może od razu zbliżyć się do Lisa, najpierw musi usiąść w pewnej odległości od niego, a dopiero następnie z biegiem czasu stopniowo się przybliżać. W tworzącej się przyjaźni potrzebne są pewne ryty przejścia, które umożliwiają wejście na kolejne etapy procesu oswajania, aż do momentu, w którym otrzymujemy zaproszenie do „małych światów” innych osób. Po drugie, Lis podkreśla wagę ustanowienia pewnych cyklicznych rytuałów, które sprawiają, że coś nabiera cech wyjątkowości. Jeśli Mały Książę będzie cyklicznie spotykał się z Lisem o ustalonej godzinie, to już wcześniej będą mogli „przygotować swe serca” na miłe spotkanie. Wyróżniony dzień spotkania stanie się wtedy wyjątkowy i będzie poprzedzony radosnym wyczekiwaniem, które znamy choćby z oczekiwania na nadejście Świąt Bożego Narodzenia. Trzecim i najważniejszym aspektem przesłania Lisa jest nauczanie o odpowiedzialności. Z przyjaźnią, która jest jedną z form miłości (philia), wiąże się także odpowiedzialność za osoby, które oswajamy, a których nie możemy porzucić, rozstać się z nimi lub zapomnieć o nich bez daleko idących konsekwencji takiego zachowania. Jeśli Mały Książę któregoś dnia zapomni o Lisie i nie będzie już przychodził na spotkania, to Lis nadal będzie czekał, a jego serce będzie doznawało tęsknoty.

Jeśli nawet do procesu oswajania podejdziemy z pełną akceptacją naszej odpowiedzialności, nigdy nie usuniemy potencjalnego cierpienia, które może zrodzić się z naszego przywiązania do innych. Oswajanie bliźnich związane jest z doznawaniem radości, ale towarzyszą temu także łzy. Ten paradoks znakomicie uchwycił Artur Schopenhauer w bajce o jeżozwierzach marznących podczas zimy ${ }^{16}$. Owe jeżozwierze pragnąc się ogrzać, starają się do siebie zbliżyć i przytulić, jednak ranią

amae, w: idem, Understanding Amae: The Japanese Concept of Need-Love, Global Oriental, Folkstone 2005, ss. 163-168. Doi wiąże przeżywanie amae z okazywaniem uczucia, które jest połączeniem przywiązania i zależności od innej osoby. W życiu człowieka amae pojawia się już w okresie wczesnego dzieciństwa, gdy dziecko przywiązane do matki jest zależne od okazywanej przez nią opiekuńczej troski. Amae dotyczy jednak także życia dorosłego i może się przejawiać w zachowaniach, poprzez które dorosła osoba chce zwrócić uwagę innych i uzyskać od nich troskliwą opiekę, opierając się na ich pobłażliwej wyrozumiałości. Przykładem takiej sytuacji może być zachowanie kobiety, która przyjmując stylistykę kawaii, przedstawia siebie jako niewinną, miłą, słabą i nieporadną dziewczynę, która potrzebuje opieki ze strony partnera. Doi powołując się na Małego Księcia, przytacza słowa Lisa, który stwierdza, że jeśli zostanie oswojony, to będzie potrzebował obecności swego przyjaciela, stanie się więc zależny od niego. W jeszcze większym stopniu amae manifestuje się w zachowaniu Róży, która w swoim przywiązaniu do Małego Księcia jest zależna od jego opiekuńczej uwagi, do tego stopnia, że manifestuje ona swoją chorowitość i kruchość po to, aby znaleźć się pod opiekuńczym kloszem swego patrona.

16 A. Schopenhauer, Metafizyka życia i śmierci, tłum. J. Marzęcki, ETHOS, Warszawa 1995, s. 104. 
je ich kolce, co sprawia, że muszą się one od siebie odsunąć. Przekładając przesłanie tego paradoksu na świat ludzkich relacji, dostrzegamy, że gdy doznajemy cierpienia, staramy się szukać pociechy w nawiązaniu relacji z innymi, sprawia to jednak, że narażamy się na inne cierpienie związane z naszym zaangażowaniem i przywiązaniem do wytworzonych więzi. Tym cierpieniem może być zdrada, porzucenie lub po prostu naturalna śmierć bliskich nam osób. Gdybyśmy się do nich nie zbliżyli i nie oswoili ich, to nie cierpielibyśmy z powodu ich utraty. W jaki sposób jednak mielibyśmy wtedy ukoić cierpienie wynikające z poczucia samotności?

\subsection{Nadzieja i pesymizm zakończenia Małego Księcia}

Zakończenie historii opowiadanej przez Saint-Exupéry’ego jest bardzo zagadkowe i pozostawia nas z licznymi pytaniami. Jedno z nich dotyczy kwestii roli Małego Księcia w jego relacji do Pilota. Czy miał on jakąś misję do wykonania? Tym zadaniem może być dokonanie przemiany Pilota lub przebudzenie pierwiastka dziecięcego tkwiącego w każdym dorosłym. Mały Książę spotyka Pilota na samym końcu swej podróży i jako dziecko przybyłe z gwiazd przekazuje swemu przyjacielowi wiedzę, jaką zdobył w jej trakcie, tym samym dziecko staje się nauczycielem dorosłego ${ }^{17}$. W zrozumieniu roli Małego Księcia pomóc może idea „zanikającego pośrednika” (vanishing mediator), którą w swych interpretacjach kultury popularnej stosuje Slavoj Žižek, a dotyczy ona takich bohaterów, którzy przybywają po to, aby udzielić pomocy innym, a gdy ich misja zostanie wykonana, to odchodzą lub giną ${ }^{18}$. Mały Książę spotyka Pilota w momencie przeżywania przez niego duchowego załamania, jego zadaniem jest przywrócenie wewnętrznej równowagi i przekazanie przyjacielowi zdolności postrzegania sercem. Dlatego gdy pod wpływem Małego Księcia Pilot przeszedł duchową przemianę, misja „zanikającego pośrednika” dobiegła końca, o on sam mógł wrócić na swoją asteroidę.

Przy refleksji nad odejściem Małego Księcia pojawia się jeszcze inne pytanie, tym razem o rolę tajemniczej Żmii, która odsyła go „do domu” swym ukąszeniem

${ }^{17}$ Mały Książę naucza często poprzez zadawanie pytań, na które Pilot musi odpowiedzieć, stosuje więc, znaną z dialogów Platońskich, metodę majeutyczną. Zob. F.H. Hetzler, Prawda fantazji a przyszłość człowieka: osoba i Mały Ksiq̨żę Saint-Exupéry’ego, tłum. H. Puszko, „,Sztuka i Filozofia” 1/1989, s. 216.

${ }^{18}$ Dla słoweńskiego filozofa przykładem takiego „zanikającego pośrednika” jest filmowy E.T. Przybywa on na Ziemię w momencie, w którym rodzina głównego bohatera filmu (Elliotta) znajduje się w stanie rozpadu i kryzysu związanego z odejściem ojca. E.T. przybywa po to, aby doprowadzić do ponownej rekonstytucji tej rodziny. Mały kosmita ścigany jest przez grupę wojskowych i rządowych naukowców, wśród nich jest jednak jeden dobry naukowiec (Keys), który pomaga E.T. i wspiera rodzinę głównego bohatera. W ostatniej scenie widzimy zapowiedź ukonstytuowania się nowej rodziny, gdyż matka z dziećmi i „dobrym naukowcem” (przyszłym ojcem) wspólnie żegnają E.T., który może już odejść, gdyż rodzina, która była rozbita, ponownie się zjednoczyła. Na tym właśnie polegała misja E.T. jako „zanikającego pośrednika”. Zob. S. Žižek, A pervert’s guide to family, https://www.lacan.com/zizfamily.htm [27.11.2019]. 
przynoszącym śmierć. Czy Żmija jest w tym przypadku szwarccharakterem? Czy jej ukąszenie może posiadać dobroczynne skutki, czy może być ono przez Małego Księcia wyczekiwane? Zauważmy, że kąsająca żmija pojawia się także w opowieści Nietzschego o Zaratustrze ${ }^{19}$. Przynosi mu ona śmierć, ale on jej nie potępia. Wręcz przeciwnie, dziękuje jej za to, że swym ukąszeniem zbudziła go ze zbyt długiej drzemki. Nie udziela też żmii przebaczenia, ale stara się dostrzec jakieś dobro w złym czynie żmii przynoszącym mu śmierć. W teologii chrześcijańskiej funkcjonuje paradoksalna idea felix culpa (szczęśliwej/błogosławionej winy), której przykładem może być upadek Adama i Ewy lub zdrada Judasza, bez których nie mogłoby dokonać się zbawienie. Jest to więc wina, z której zrodzić się może większe dobro. Ukąszenie węża przynosi kres ziemskiej wędrówki Małego Księcia i wywołuje także ból w sercu Pilota spowodowany rozstaniem z przyjacielem, który jednak może dzięki temu powrócić do domu i pojednać się z Różą. Zaratustra zapewne nie potępiłby Żmii Małego Księcia, szukałby raczej jakiegoś dobra wynikającego z tego złego czynu, jakiejś szczęśliwej winy, bez której jakieś dobro nie mogłoby się wydarzyć.

Zniknięcie Małego Księcia doprowadza nas do ostatniego rysunku zamykającego książkę Saint-Exupéry’ego. Przedstawia on już tylko nocny krajobraz pustyni, nad którą unosi się niebo z błyszczącą gwiazdą. To niejednoznaczne zakończenie pozostawia nas w stanie niepokoju. Tak naprawdę nie wiemy, w jakim nastroju możemy zakończyć lekturę, gdyż nadzieja miesza się z pesymizmem. Z jednej strony Mały Ksiq̨żę to dzieło napisane ku pokrzepieniu serc, które w mrocznych czasach drugiej wojny światowej daje nadzieję na przetrwanie ideałów humanizmu. W takim przypadku obserwowana gwiazda jest iskierką będącą drogowskazem w mrokach nocy, jest też nawiedzającym nas przesłaniem z innego świata. Z drugiej strony ostatni obraz, na którym nie ma już żadnego z bohaterów, może budzić pesymistyczny nastrój pustki. Ostatecznie pustynia pozostaje pustynią, nie zmienia się w rozkwitającą oazę. Pilot doznaje głębokiej przemiany, ale musi wrócić do świata dorosłych, w którym będzie obcym przybyszem. Czy uda mu się w nim zadomowić, czy też nie znalazłszy zrozumienia, będzie musiał wracać na pustynię, która stanie się jego jedynym azylem? Zniknięcie Małego Księcia można też odczytywać jako porażkę humanizmu oraz romantycznej wizji świata, z których można by czerpać siłę do przemiany życia. Z gwiazd podziwianych na niebie wcale nie musi wypływać nadzieja, gdyż tak naprawdę ich światło (docierające na Ziemię z opóźnieniem) może być tylko widmową ułudą, a one same mogą już nie istnieć. Także dzisiejsza kultura masowa, której zubożającego wpływu obawiał się Saint-Exupéry, nie przynosi nam nadziei na odnalezienie pokoju w gwiazdach, gdyż przekonuje nas ona, że świat gwiazd też będzie okrutny, gdyż będzie światem gwiezdnych wojen ${ }^{20}$.

${ }^{19}$ F. Nietzsche, Tako rzecze Zaratustra, tłum. W. Berent, Zysk i S-ka, Poznań 2000, ss. 59-60.

20 Zachowane rękopisy wczesnych wersji Małego Księcia pokazują, że pierwotnie epilog kończący książkę miał mieć dużo bardziej pesymistyczną wymowę niż zakończenie, które 


\section{Zakończenie}

W humanistycznej filozofii Małego Księcia można wyróżnić kilka najważniejszych postulatów. Pierwszy z nich głosi pierwszeństwo serca przed rozumem, przy czym nie jest to nawoływanie do negacji rozumu i pogrążenia się w skrajnym irracjonalizmie. Nie zapominajmy, że Exupéry w swym życiu łączył poetycką wrażliwość humanisty z zainteresowaniem naukami ścisłymi, co pozwoliło mu wprowadzić kilka innowacyjnych usprawnień technicznych do samolotów, którymi wybierał się na długie, samotne, nocne medytacje. Sam samolot, będący narzędziem technicznym, służył mu jako środek do celu poznania planety i samego siebie ${ }^{21}$. Głos serca ma więc wybrzmieć głównie jako krytyka nadużyć rozumu, który racjonalizując wszystkie obszary naszego życia, przemienia je w jałową wegetację przy taśmowej produkcji fabrycznej. W drugim postulacie zawarte jest przeświadczenie, że proces konstytuowania podmiotowości własnego Ja jest nierozerwalnie związany z tworzeniem więzi z innymi. Dlatego filozofię Małego Księcia można określić mianem filozofii spotkania. Postulat ten uzupełnia inny, głoszący nieuniknioność rozstania i wynikającego z tego cierpienia. Nie jest to więc naiwna filozofia, która konstruowałaby utopijną wizję cukierkowego, dziecięcego świata, w którym miłość raz na zawsze usuwa wszelkie zło. Jest to także filozofia, która przypominając o fundamentalnych wartościach, stara się odpowiedzieć na egzystencjalny, duchowy, moralny i cywilizacyjny kryzys wywołany przez traumatyczne wydarzenia wojenne i gwałtowne przemiany społeczne zainaugurowane w XX wieku. Ten głęboki kryzys opisywał Saint-Exupéry (w Liście do Generała $X^{22}$ ) jako duchową pustkę jego pokolenia sprowadzonego do roli ludzi-robotów i ludzi-termitów, czyli taśmowych producentów masowych produktów konsumowanych następnie bez opamiętania. Temu wszystkiemu towarzyszy powierzchowność tworzonych więzi. Do przedmiotów, które łatwo wymienić na nowe, nie trzeba się przywiązywać, a to przekłada się także na relacje z ludźmi, którzy zaczynają być traktowani jak zastępowalne części wymienne. Przy takim braku prawdziwych więzi kategorie wierności i niewierności przestają obowiązywać, co jeszcze bardziej podkreśla pustkę takiej egzystencji. Dlatego jednostka, która poszukiwałaby jakiegoś głębszego sensu, musiałaby się

znalazło się w ostatecznej wersji. Był to wręcz lament nad gwiazdami, na których ktoś traci przyjaciela, ciężko choruje lub toczy wojny. Zob. The Little Prince: A New York Story (Full Press Release), https://www.themorgan.org/sites/default/files/pdf/press/LittlePrincePressRelease. pdf [27.11.2019].

${ }^{21}$ A. de Saint-Exupéry, Ziemia, planeta ludzi, tłum. W. Bieńkowska, Z. Bieńkowski, Siedmioróg, Wrocław 2017, ss. 33-43; A. Bukowska, Saint-Exupéry czyli paradoksy..., ss. 17, 36; Z. Bieńkowski, Saint-Exupéry, aprobata cywilizacji, w: idem, Piekła i Orfeusze. Szkice z literatury zachodniej, Oficyna Wydawnicza Łośgraf, Warszawa 2009, s. 36.

${ }^{22}$ A. de Saint-Exupéry, O sens życia, tłum A. Wasilewska, PIW, Warszawa 2007, ss. 155-161. 
przebudzić, aby ponownie narodzić się do człowieczeństwa ${ }^{23}$. To doprowadza nas do najważniejszego postulatu filozofii Małego Księcia, którym jest wezwanie do odnalezienia w sobie utraconego skarbu więzotwórczego postrzegania sercem, bez którego nie można osiągnąć w pełni dojrzałego człowieczeństwa, nie można ocalić Ziemi - planety ludzi.

\section{Literatura}

Bieńkowski Z., Saint-Exupéry, aprobata cywilizacji, w: idem, Piekła i Orfeusze. Szkice z literatury zachodniej, Oficyna Wydawnicza Łośgraf, Warszawa 2009.

Borowski D., Literackie nawiqzania do Małego Księcia Antoine’a de Saint-Exupéry’ego - spojrzenie intertekstualne, w: Z. Ożóg-Winiarska (red.), Teksty kultury w edukacji polonistycznej i refleksji badawczej, Wydawnictwo Uniwersytetu Jana Kochanowskiego, Kielce 2014.

Bukowska A., Saint-Exupéry czyli paradoksy humanizmu, PIW, Warszawa 1970.

Doi T., On the concept of amae, w: idem, Understanding of Amae: The Japanese Concept of Need-Love, Global Oriental, Folkstone 2005.

Drewermann E., Istotnego nie widać. Rzecz o Małym Księciu, tłum. Jerzy Prokopiuk, W.A.B., Warszawa 1996.

Freud Z., Żałoba i melancholia, tłum. B. Kocowska, w: K. Pospieszył (red.), Zygmunt Freud: człowiek i dzieło, Zakład Narodowy im. Ossolińskich, Wrocław 1991.

Heidegger M., Bycie i czas, tłum. B. Baran, Wydawnictwo Naukowe PWN, Warszawa 2005.

Hetzler H.F., Prawda fantazji a przyszłość człowieka: osoba i Mały Ksiqżę Saint- Exupéry’ego, tłum. H. Puszko, „Sztuka i Filozofia” 1/1989.

Jung M., Mały Ksiq̨żę w nas: w podróży odkrywczej z Saint-Exupérym, Księgarnia Świętego Wojciecha, Poznań 2006.

Kwiatkowski W., Saint-Exupéry: samotność i więź, Wydawnictwo Uniwersytetu Marii Curie-Skłodowskiej, Lublin 2003.

Kwiatkowski W., Saint-Exupéry w świetle krytyki, w: idem (red.), Humanizm Saint- Exupéry'ego, Pax, Warszawa 1969.

Meyer C.B., The Little Prince: speculations on the disappearance of Antoine De Saint-Exupéry, „Journal of American Psychoanalytic Association” 1(22)/1974.

Nietzsche F., Tako rzecze Zaratustra, tłum. W. Berent, Zysk i S-ka, Poznań 2000.

Potočárová M., The educational and moral message in Antoine de Saint Exupéry's The Little Prince, „Studia Paedagogica Ignatiana” 4(20)/2017.

Saint-Exupéry A., Mały Ksiq̨żę, tłum. E. Łozińska-Małkiewicz, ALGO, Toruń 1998.

Saint-Exupéry A., O sens życia, tłum. A. Wasilewska, PIW, Warszawa 2007.

Saint-Exupéry A., Ziemia, planeta ludzi, tłum. W. Bieńkowska, Z. Bieńkowski, Siedmioróg, Wrocław 2017.

Schopenhauer A., Metafizyka życia i śmierci, tłum. J. Marzęcki, ETHOS, Warszawa 1995. Świeżyński A., „,Czy baranek zjadł różę?” Próba symboliczno-biblijnej interpretacji Małego Księcia Antoine de Saint-Exupéry, „Studia Gdańskie” XXI, 2007.

${ }^{23}$ A. Bukowska, Saint-Exupéry czyli paradoksy..., s. 114. 
Žižek S., Lacrimae rerum: Kieślowski, Hitchcock, Tarkowski, Lynch, tłum. G. Jankowicz, J. Kutyła, K. Mikurda, P. Mościcki, Wydawnictwo Krytyki Politycznej, Warszawa 2007.

\section{Źródła internetowe}

Mickiewicz A., Romantyczność, https://wolnelektury.pl/katalog/lektura/ballady-i-romanse-romantycznosc.html.

Žižek S., A pervert’s guide to family, https://www.lacan.com/zizfamily.htm. 
